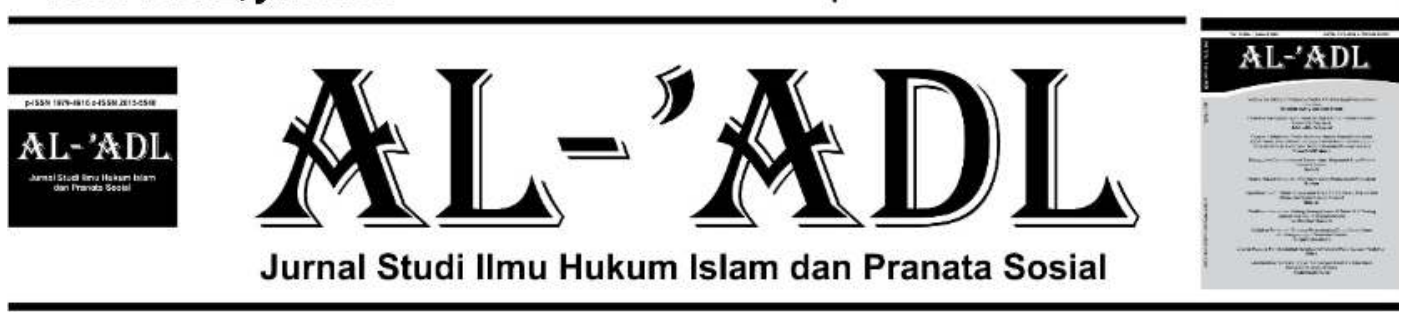

journal homepage : ejournal.iainkendari.ac.id/al-adl

\title{
The Using of Maslahah Mursalah Method as Hujjah
}

\section{Muh. Idris', Finsa Adhi Pratama ${ }^{2}$, Lian Mulyani Muthalib ${ }^{3}$}

${ }^{1}$ Program Studi Hukum Keluarga Islam, Fakultas Syariah, IAIN Kendari, Indonesia ${ }^{2}$ Program Studi Hukum Ekonomi Syariah (Muamalah), Fakultas Syariah, IAIN Kendari, Indonesia

${ }^{3}$ Program Studi Hukum Tata Negara, Fakultas Syariah, IAIN Kendari, Indonesia

E-mail: idrismuh814@gmail.com ${ }^{1}$, finsaadhipratama@iainkendari.ac.id ${ }^{2}$, lian.engdept@gmail.com ${ }^{3}$

\section{ARTICLE INFO}

Article History :

Received: 2021-04-22

Accepted: 2021-04-29

Published: 2021-07-31

Keywords :

Hujjah, Istimbath, Maslahah Mursalah

(C) 2021 Al-'Adl. All rights reserved

ABSTRACT
After the death of the Prophet Sallallahu 'alaihi
Wasallam, all the problems of Muslims are submitted
to the scholars to look up for solutions from texts.
The scholars are required to perform ijtihad in order
to solve the problems arised by digging into the
values of the text of the Qur'an and Hadith, in which
the ijtihad will develop into ijtihad bir-ra'yi if the
solutions cannot be found in the texts. There have
been numerous methods used to deeply explore the
laws such as ijma', qiyas, as well as istidlal like
Istishab, Maslahah Mursalah, Al-Ihtihsan, Qoulu
Shohaby, Syadd ad-Dzaro'i, Dilalah al-Iqtiran,
Dilalah al-Ilham, Ru'yan of Prophet Sallallahu 'alaihi
Wasallam, and Syar'u Man Qoblana. All decisions
from Allah Ta'ala definitely has the benefit value as
it is impossible for Allah Ta'la to make a decision
that is in vain. Starting from these values then born
the Istimbath which is Maslahah Mursalah law. So,
this discussion focuses on the meaning of maslahah
mursalah, the background for the birth of the
maslahah mursalah method, the division of maslahah
mursalah, and the validity of maslahah mursalah as


istidlal in ushul fiqh. This study uses literature review method by relying on the strength of references and strong analysis of literacy texts. The conclusion that can be drawn from this discussion is that maslahah mursalah is something that is beneficial for humans as the goal of syara'. There are differences of opinion regarding the position of maslahah mursalah in Islamic law, in which some accept it and some reject it to be used as hujjah. However, the two of them met at the point that the groups that reject is the maslahah that only based on lust and mind, they do accept maslahah as hujjah if it is in line with what is required by syara'.

\section{A. Introduction}

Since the beginning, Islam has been known as a religion that has syumul, universal and comprehensive values that will always be in accordance with the times and places (sholihun likulli Zamanin wa Makan) based on the God's instruments. As the time flies along with the amount of problems arise, Islam is required to provide solutions of problems in all situations.

At the time of prophethood, all problems that arose in the midst of Muslims could be immediately resolved by the Prophet Muhammad Sallallahu 'alaihi Wasallam through revelation. However, after the death of the Prophet Sallallaahu 'alaihi Wasallam in 11 H (633 AD), all the problems of the Muslims are submitted to the scholars to look up for solutions from texts, as there are many problems arise that previously were not encountered at the time of the Prophet Sallallahu 'alaihi Wasallam still alive.

During the time of fellowship, the fellows were required to perform ijtihad in order to solve the problems faced by the human race by digging into the values of Qur'an and tracing the Hadiths of the Prophet Sallallahu 'alaihi Wasallam if the solutions were not found in the Qur'an. If necessary, this ijtihad will develop into ijtihad bir-ra'yi - whether ijma', qiyas or istidlal - by not breaking the main texts.

In its development, numerous methods are found in exploring a law known apart from the core arguments (al-Qur'an and al-Hadith) such as ijma', qiyas, as well as istidlal like Istishab, Al-Masholih al-Mursalah, Al-Ihtihsan, Qoulu Shohaby, Syadd ad-Dzaro'i, Dilalah al-Iqtiran, Dilalah al-Ilham, Ru'yan of Prophet Sallallaahu 'alaihi wasallam, and Syar'u Man Qoblana. 
It can be observed that all the decisions from Allah Ta'ala - whether obligatory, sunnah, permissible, or haraam - must have a benefit value, and this is what every Muslim believes as it is impossible for Allah Ta'la to make a decision that is in vain without having good benefits, either directly or indirectly. Many texts indicate that the purpose of Allah Ta'ala in setting the law is for the benefits of human life and to keep people away from all forms of damage, in which the benefits apply in the world and the hereafter. Starting from these values then born the Istimbath which is Maslahah Mursalah law.

Maslahah Mursalah is one of the legal istimbath methods that does not rely directly on the Qur'an and Hadith yet it still has the goal of realizing maslahah. This is supported by the ushul fiqh rule "taghyirul hukmi bi taghyiri az-zaman wa al-makan" which means: "the laws can change due to changes in times, places and circumstances". This rule implies that sometimes a law can change in certain circumstances and times with the value of maslahah because basically Maslahah mursalah is one of the legal istimbath methods that emphasizes aspects of benefit in decision making.

The discussion that arises afterwards is about the hujjah of Maslahah Mursalah as the syara' argument. Many scholars argue that Maslahah Mursalah can be used as a law, yet not a few scholars reject it. Even a great scholar like Imam Shafi'i did not mention Mashallah Mursalah in his istimbath theory, thus it is not certain whether he accepts or rejects Mashallah Mursalah.

In fact, if humans carry out God's law properly in accordance with the guidance of the Qur'an and Hadith, then the happiness of the benefit of the hereafter will be realized. Although the benefit is the main goal of the revelation of the syara law to the earth, not all things that is judged to be beneficial for humans is in accordance with the syara' arguments. This Maslahah Mursalah is expected to be one of the contextual istimbath methods that can contribute to problem solving towards the problems that arise in human life. In the Al-Bayan book by Abdul Hamid Hakim it is stated that Maslahah Mursalah is included in one of the istidlal methods in Usul Fiqh. ${ }^{1}$

Based on the view above, the discussions related to maslahah mursalah need to be dealt with that it can provide solutions to community problems. Therefore, this discussion focuses on the meaning of maslahah mursalah, the background for the birth of the maslahah mursalah method, the division of

${ }^{1}$ Aldul Hamid Hakim, 2007, Al-Bayan, Maktabah As'adiyah Putra, Jakarta, p. 128. 
maslahah mursalah, and the validity of maslahah mursalah as istidlal in ushul fiqh.

\section{B. Discussion}

\section{Definition of Maslahah}

Before discussing Maslahah Mursalah and its use as a legal argument, the author first puts forward the meaning and nature of Maslahah itself.

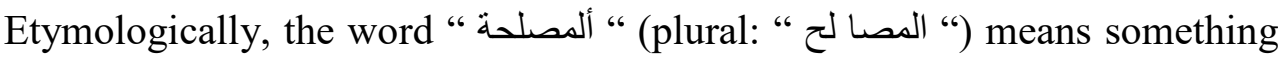
good, beneficial, and it is the opposite of evil or damage, at which in Arabic it is often referred to " الخيرو الصو اب "which means what is good and right.

Literally, Istishlah means: "looking for Maslahat (benefit)". Meanwhile, Istishlah in terms means establishing the law of a matter for which there is no text or no ijma' against it, that based on mere benefit (which by syara' is neither explained nor prohibited). ${ }^{3}$ Maslahat is sometimes referred to " ألإستصلا " which means seeking the good. ${ }^{4}$

Furthermore, in al-Mustafa, it is stated that:

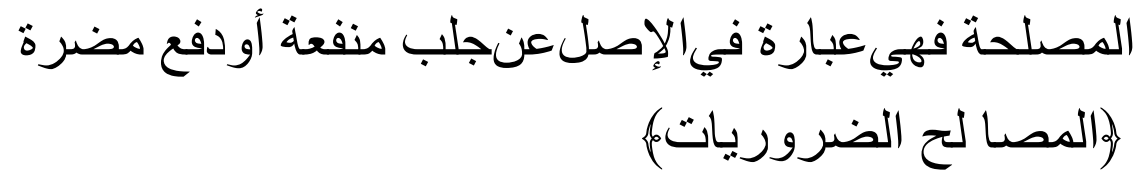

Meaning: "Maslahat is basically trying to achieve and realize the benefits or reject the harm". 5

From several meanings or definitions above, it can be concluded that Maslahah Mursalah is everything that is beneficial to humans - whether those that are useful for achieving goodness and pleasure as the goals of syara' - not the benefits that are solely based on human desires, nor those that eliminate difficulties and troubles.

\section{Requirements for Maslahah Mursalah}

Regarding the requirements for using maslahah mursalah, there are indeed differences among Ushul scholars, both from the terms and the numbers, namely:

2Jalaluddin Abdurrahman, 1983, al-Masalih al-Mursalah wa Makanatuha fi al-Tasyri', $1^{\text {st }}$ printed, Matba'ah al-Sa'adah, Mesir, p. 12.

${ }^{3}$ Zarkasji Abdul Salam, 1986, Introduction to Fiqh-Ushul Fiqh, $1^{\text {st }}$ printed, CV. Bina Usaha, Yogyakarta, p. 121. 157.

${ }^{4}$ Romli, 1999, Muqaranah Mazahib Fil Ushul, $1^{\text {st }}$ printed, Gaya Media Pratama, Jakarta, p.

${ }^{5}$ Imam al-Ghazali, 1977, al-Mustafa, Maktabah al-Jundiyah, Mesir, p. 251. 
a. The benefit that is in accordance with the objectives of the shari'a

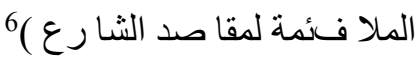

b. The benefit of mursalah should be logical and compatible with reason. ( ان يكون معقولة في ذاتها جرت عليالا وصاف المنا سبة المعقو لة )

c. The benefit should involve the emergency problems ( ان تكون المصلحة ضرورية It means that it is required that the benefit is to maintain emergency problems, such as those relating to the maintenance of religion, life, property, lineage and reason. ${ }^{8}$

d. The benefit is the kuliyah benefit, not the juziyah ( ان يكون المصلحة كلية لاجرئية ). It means the benefit that brings benefits to all Muslims, not just a part of it. ${ }^{9}$

e. The benefit that is achieved with istishlah must be the true benefit. It means maslahah that can bring benefits and avoid harm.

f. The benefit achieved by istishlah must be for the general benefit, not for the benefit of individuals or groups. It is clear that the benefit must be able to give benefit the majority of the community to some others.

g. The benefit achieved by istishlah does not conflict with the texts of syara' or ijma'. ${ }^{10}$

h. The maslahah mursalah should be the benefits agreed upon by the Muslims about its existence and proven to be practiced in their lives ( 11 (يجتمع فيها أر اء المسلمين علي إعنبار ها

From the requirements of maslahah mursalah that have been stated above, although there are differences among Usul Fiqh experts, it can be concluded that what is important is that maslahah mursalah must be in line with the objectives of syara', needed by humans, and their interests can be protected.

\section{Division of Maslahat}

Maslahat can be divided into two types, which are based on its level and its existence.

\section{a. Maslahat according to Its Level 1) Maslahat Daruriyat}

${ }^{6}$ Muhammad Abu Zahrah, 1958, Ushul al-Fiqh, Dar al-Fikr al-‘Arabi, Kairo, p. 279.

${ }^{7}$ Ibid., p. 280.

${ }^{8}$ Jalaluddin Abdurrahman, op.Cit., p .50.

${ }^{9}$ Ibid., p .51.

${ }^{10}$ Zarkasji Abdul Salam, op.Cit., p. 123 - 124.

${ }^{11}$ Jalaluddin Abdurrahman, op.Cit., p .52. 
The Maslahat at this level refers to the benefit as the basis for upholding human life, both related to religion and the world. If it misses from human life, it will destruct the system of human life.

According to Zakaria al-Biri, this maslahat daruriyat is a fundamental basis for ensuring the viability of humans. Once it is damaged, then there will be slander and great disaster. ${ }^{12}$ There are five aspects included as the scope of this maslahat daruriyat namely matters relating to the maintenance of religion, soul, mind, lineage and property.

The five kinds of aspects are included in the most basic benefit. These aspects must be maintained and protected, as if they are disturbed, there will be damage to the sytem in human life.

\section{2) Maslahat Hajiyat}

This type of maslahat refers to the matters needed by humans to eliminate the difficulties and troubles they face. As put forward by Hasbi Ash-Shiddieqy, complementing everything that is needed by humans to make it easier and to be able to bear the difficulties of taklif and the burdens of life. ${ }^{13}$

In terms of importance, this kind of maslahat is in lower level than the maslahat daruriyat. All the legal provisions that are prescribed to relieve and facilitate human interests are the reliefs brought by Islamic doctrine, such as being allowed to break the fast for travelers and people who are sick, doing qashar of prayers while on travel, etc. The examples mentioned are the benefits that humans need. If it is not actualized in life, it will only cause difficulties, not shocks and damage.

\section{3) Maslahat Taksiniyah}

This maslahat is also known as maslahat takmiliyah. The nature of this maslahat is to maintain only the fineness and goodness of character as well as the beauty. If this maslahat cannot be actualized in life, it will not cause difficulties ands shocks nor damage the system in human life. ${ }^{14}$

This maslahat concerns more on beauty alone. Nevertheless, this kind of maslahat are still needed by humans. For instance, in

${ }^{12}$ Hasbi Ash-Shiddieqy, 1981, Introduction to Islamic Law I, $6{ }^{\text {th }}$ printed, Bulan Bintang, Jakarta, p. 81.

\footnotetext{
${ }^{13}$ Ibid., p. 82.

${ }^{14}$ Jalaluddin Abdurrahman, op.Cit., p. 2.
} 
matters of worship to Allah SWT, there have been prescribed various forms of chastity, covering aurat, and dressing beautifully. As in the hadith of the Prophet Muhammad, it is also recommended to wear perfumes which are basically human pleasures. This maslahat also includes, for example, those relating to etiquette and procedures for eating and drinking as well as cleaning oneself. All the benefits that are categorized into this maslahat tahsiniyah are only for goodness and perfection. If it cannot be actualized and achieved by humans, it will not complicate and damage their system of life, yet it is still considered as important and necessary.

From the division of maslahat according to its levels, it can be seen that maslahat can be distinguished substantially. Indeed, in practice and efforts to make it actualized in life, there may be a clash among the three kinds of maslahat aforementioned. Hence, there should be a serious concern on it.

If there is a clash between two maslahats, e.g. the maslahat daruriyat and the maslahat hajiyat, then maslahat daruriyat should take precedence over maslahat hajiyat. It is due to maslahat daruriyat involves the most basic important sectors in life that cannot be negotiated. If it is disturbed and not protected, it will result in the destruction of human life system.

It is a different case for maslahat hajiyat. This maslahat is indeed important and needed and therefore should be maintained, yet if it cannot be actualized in life, it will only cause difficulties for humans and not lead to the destruction of life. Likewise, between maslahat hajiyat and maslahat tahsiniyat, maslahat hajiyat should take the precedence. It is due to the maslahat hajiyat occupies a higher position than maslahat tahsiniyat. The maslahat tahsiniyat is only to complete and complement the other maslahats, not to damage life once it is not actualized.

\section{b. Maslahat according to Its Existence}

According to its existence, maslahat is divided into three categories as follows:

\section{1) Maslahat Mu'tabarah}

This type of maslahat refers to the benefits in which the texts clearly explain and acknowledge its existence. In other words, 
benefits that are recognized by syar'i and there are clear arguments to

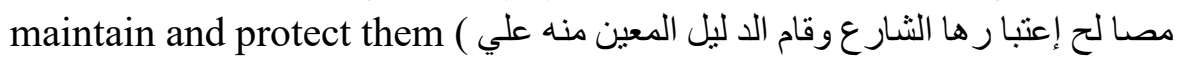
رعا يتها ${ }^{15}$

If the syar'i mentions in the texts about the law of an event and mentions the value of the maslahat which it contains, then it is called as maslahat mu'tabarah. This maslahat includes all the benefits described and mentioned by the texts, such as maintaining religion, soul, lineage and property. Therefore, Allah SWT has decreed to strive with jihad to protect religion, to carry out qishash for murder, to punish those who drink alcoholic beverages, to punish those who commit adultery, and to punish the perpetrators the thieves. All scholars agree that all benefits that are categorized as maslahat mu'tabarah must be enforced in life, as seen from its level, this maslahat the main interest that should be enforced. ${ }^{16}$

\section{2) Maslahat Mulghah}

This maslahat refers to the benefit that is contrary to the provisions of the texts. In other words, the benefit that exists because there are arguments that show that it is contrary to the provisions of clear arguments. An example that is often shown by Usul scholars is equating the distribution of inheritance between a daughter and a son. The equality between a daughter and a son regarding inheritance does seem to have its benefits, but it is contrary to the provisions of clear and detailed textual arguments. As it is mentioned in the Qur'an:

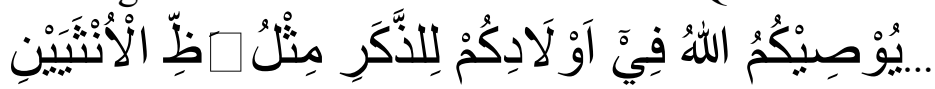

Meaning: "Allah prescribes for you about (the distribution of inheritance for) your children. Namely: the share of a son is equal to the share of two daughters ..." (QS. an-Nisaa'/4: 11).

The verse above explicitly mentions the division of inheritance where the share of a son is equal to the share of two daughters. So, if the inheritance is divided equally, does it mean that the share of a son is equal to the share of a daughter? The reason is that the presence of the daughter in the family is equal to that of the son. The reason that can be seen and understood from explicit text is that the value of a son 
is equal to that of two daughters, that is, one to two. It means that the reason ('illat) of the division of inheritance in the texts due to gender differences. Because of creating the benefit, the division was changed so that between a son and a daughter got an equal share in the inheritance. Match boys to girls with one welding an benefit as it is called by the maslahat mulghah, as opposed to the sarih texts.

\section{3) Maslahat Mursalah}

This maslahat refers to the benefit in which there is no explicit argument that either admits it or rejects it. More explicitly, it is a type of maslahat that the texts ignore.

Therefore, this maslahat is in line with the goals of syara' that can be used as a basis for actualizing the goodness that humans desire and for avoiding harm. It is admitted that in reality this last type of maslahat continues to grow and develop along with the development of Islamic society that is full of differences in conditions and places.

Jalaluddin Abdurrahman and Romli divide this maslahat mursalah into two types, namely: ${ }^{17}$

a) Maslahat that is basically in line with and in accordance with what is brought by the shari'ah.

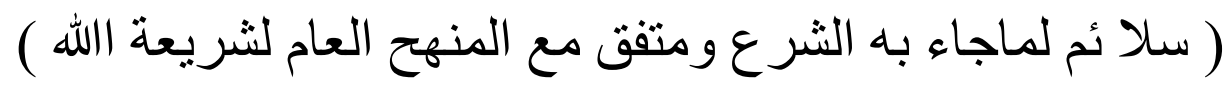

In other words, this type of Maslahat is related to Maqasid alSyari'ah, which is to actualize the goal of shari'ah that is daruri (principal).

b) Maslahat that is vague in nature which needs the sincerity of mujtahids to actualize it in life.

\section{The Position and The Hujjah of Maslahah Mursalah}

It is undeniable that there are differences of opinion among the Usul sect regarding the position and the hujjah of maslahah mursalah in Islamic law, both those who accept it and those who reject it. The following description will explain the differences of opinion between the Usul sects who accept and reject it as well as their respective arguments.

a. The first group said that maslahah mursalah is one of the sources of law and at the same time is the hujjah of shari'ah. This opinion is followed

${ }^{17}$ Jalaluddin Abdurrahman, op.Cit., p. 165. 
by the Maliki and Ahmad Ibn Hanbal sects. According to Abdul Karim Zaidan $^{18}$, Imam Malik and his followers as well as Imam Ahmad Ibn Hanbal made the maslahah mursalah a legal argument and hujjah in establishing the law. ${ }^{19}$

Followings are the arguments from the first group:

1) According to this group, it is explained that the fellows had compiled the Qur'an in a mushaf and this was carried out as they were afraid that the Qur'an could be lost. This matter did not exist at the time of the Prophet Muhammad and there was no prohibition about it. The compilation of the Qur'an in one mushaf is solely for the benefit of the people. Practically, the fellows have used the maslahah mursalah, in which there is not a single argument forbidding or ordering them to do so. ${ }^{20}$

2) In fact, the fellows have used the maslahah mursalah in accordance with the goals of syara', thus it should be practiced according to that goals. Once it is neglected, it means that the goals of Shari'ah are also neglected, which is null and cannot be accepted. Hence, adhering to maslahat is an obligation, as it is one of the main grips of the other grips, in which there is indeed a meeting point. ${ }^{21}$

3) The purpose of the law is to realize the benefits and reject the damage in human life. It is undoubtedly that the maslahat keeps growing as time flies and that it continues to change with the changing of situation and environment. If the maslahat is not observed carefully and is not responded by appropriate provisions unless it is fixed on the argument that admits it - surely the maslahat will disappear from human life and it will stop the growth of the law. The attitude that does not pay attention to the development of maslahat is not in line with what is the goals of the Shari'ah, which are realizing benefit and rejecting damage in human life.

This third reason is the key for the first group in maintaining the position of maslahah mursalah as hujjah shari'ah. As if the maslahats that exists in every place are ignored, while it remains in line with

\footnotetext{
${ }^{18}$ Romli, op.Cit., p. 168.

${ }^{19}$ Muhammad Abu Zahrah, loc.Cit.

${ }^{20}$ Ibid., p. 280.

${ }^{21}$ Romli, loc. Cit.
} 
the will of the Shari'ah, it is surely that humans will experience difficulties, though Allah Ta'ala does not want difficulties for humans. ${ }^{22}$

b. The second group that rejects the maslahah mursalah as hujjah of shari'ah. This second group argues that the maslahah mursalah cannot be accepted as hujjah in establishing the law. The Hanafi, the Shafi'i, and the Zahiriyah Sects are included in this second group. The arguments from this second group are as follows: ${ }^{23}$

1) According to this second group, Allah Ta'ala (shar'i) rejecting some maslahats and accepting the others, while maslahah mursalah is dubious. As it perhaps the maslahah mursalah is rejected and its existence is recognized by the shar'i. Therefore, the maslahah mursalah possibly cannot be used as an excuse in legal making.

2) In fact, using the maslahah mursalah in determining the law is taking a path based on lust, which in this case it is not permissible.

3) This second group then said that using maslahah mursalah means that it will cause legal differences due to the differences in time and environment. In fact, the maslahat will always change with the changing of times and situations. Indeed, this will eliminate the general function of the Shari'ah and its values that apply to every time and place.

By looking at the differences of opinion between groups that accept the maslahah mursalah as hujjah of shari'ah and those who reject it, as well as their respective reasons, it turns out that the root of the difference lies in their respective views on the maslahah mursalah itself.

The first group represented by Imam Malik and his followers as well as Imam Ahmad Ibn Hanbal argued that the maslahah mursalah they reffered to was the maslahat that based on the conditions given by syara', not based on lust or deviating from the truth as the second group views. Meanwhile, the second group represented by the Hanafi, the Shafi'i, and the Zahiri sects, argued that the maslahah mursalah is a maslahat that is doubtful and cannot be used as hujjah, which according to the first group it is not true. The first group argued thet the maslahah

${ }^{22}$ Muhammad Abu Zahrah, op.Cit., p. 282.

${ }^{23}$ Romli, op.Cit., p. 170. 
mursalah is based on the search for harmony and in line with the goals of the Shari'ah. For the first group, the maslahat besides what is mentioned by the texts, also includes all the maslahats desired by the shar'i to be maintained by paying attention to its compatibility to realize them, though there is no text that explains it, it is still in line with the goals of the shari'ah. This kind of maslahat is called the maslahah mursalah.

On the other hand, the second group explained that all the maslahats had been explained by the texts, both the accepted and the rejected ones. If you are trying to find benefits other than the provisions of the text. According to the Zahiri sect, the maslahah mursalah they accept is the one that clearly stated in the texts and they reject it if it is not indicated by the texts. ${ }^{24}$

This view is also in line with Hanafi, the Shafi'i follower, who forbid to hujjah with the maslahah mursalah. However, this view says that Imam Shafi'i and some of the followers of Imam Abu Hanifah and Ibn Taymiyya, all of them hold and hujjah the maslahah mursalah and claim it as a legal argument as long as it is one of the things required by the shar'i to be maintained. ${ }^{25}$

After observing the differences of opinion of the Usul Fiqh scholars regarding the position of maslahah mursalah in Islamic law, the author can conclude that actually between the groups that accept maslahah murasalah and those who reject it, both of them basically have a common ground that the second group does not completely reject maslahah mursalah. It means that the second group emphasizes that if the maslahah mursalah as the grip of the first group can indeed be categorized as maslahat that are required by syar'i to be maintained, not only based on lust and mind, then the second group accepts it. It seems that the group that rejects the maslahah mursalah emphasizes caution in using maslahah mursalah. Basically, it does not mean that the group that accepts the maslahah murslah and makes it as a proposition is not paying attention to the requirements. For the first group, the matters of maslahah mursalah that they deal with is the ones that are in line with the goals of the shari'ah. In other words, maslahah 
mursalah is part of the shari'ah that cannot be ruled out, though it is not mentioned textually in the texts, substantially it is desired by humans, especially those that are directly relate to their basic needs.

\section{Conclusion}

Based on the result of the discussion above, it can be concluded that maslahah mursalah refers to all things that are beneficial to human beings for achieving goodness and pleasure as the goals of syara', not the benefits that are solely based on the desires of human beings, nor those that are designed to eliminate difficulties and troubles.

Although there are differences among Usul scholars regarding the requirements for maslahah mursalah, the scholars basically agree that the most important thing is that maslahah mursalah should be in line with the goals of syara', should be needed by humans, and could protect their interests.

In general, Maslahat can be divided based on its level and its existence. According to its level, Maslahat is divided into three categories, namely: Maslahat Daruri, Maslahat Hajiyat and Maslahat Tahsiniyah. Meanwhile, according to its existence, Maslahat is also divided into three categories, namely: Maslahat Mu'tabarah, Maslahat Mulghah and Maslahat Mursalah.

After observing the differences of opinion of the Usul Fiqh scholars regarding the position of maslahah mursalah in Islamic law, the author concludes that even though they have different opinions about whether or not it is permissible to be a hujjah, there is basically a common ground; it means that the groups that reject maslahah mursalah is the maslahah that only based on lust and mind. As for the maslahah required by the syar'i to be maintained, they still accept it as the group that accepts the maslahah mursalah as hujjah.

\section{References}

\section{Books}

Abd. Madjid, Ahmad, 1989, Muhadrarah Fi Ushul al-Fiqh, IAIN Sunan Ampel, Surabaya.

Abdul Salam, Zarkasji, 1986, Pengantar Ilmu Figh-Ushul Fiqh, $1^{\text {st }}$ printed, CV. Bina Usaha, Yogyakarta.

Abdurrahman, Jalaluddin, 1983, al-Masalih al-Mursalah wa Makanatuha fi alTasyri', $1^{\text {st }}$ printed, Matba'ah al-Sa'adah, Mesir. 
Abu Zahrah, Muhammad, 1958, Ushul al-Fiqh, Dar al-Fikr al-'Arabi, Kairo.

Al-Ghazali, Imam, 1977, al-Mustafa, Maktabah al-Jundiyah, Mesir.

Ash-Shiddieqy, Hasbi, 1964, Al-Islam I, Bulan Bintang, Jakarta.

Ash-Shiddieqy, Hasbi, 1971, Sejarah Pertumbuhan dan Perkembangan Hukum Islam, Bulan Bintang, Jakarta.

Ash-Shiddieqy, Hasbi, 1973, Pokok-Pokok Pegangan Imam-Imam Mazhab, Bulan Bintang, Jakarta.

Ash-Shiddieqy, Hasbi, 1978, Pengantar Ilmu Fiqh, Bulan Bintang, Jakarta.

Ash-Shiddieqy, Hasbi, 1981, Pengantar Hukum Islam I, $6^{\text {th }}$ printed, Bulan Bintang, Jakarta.

Daud Ali, Mohammad, 1996, Hukum Islam/Pengantar Ilmu Hukum dan Tata Hukum Islam di Indonesia, $5^{\text {th }}$ printed, PT. Raja Grafindo Persada, Jakarta.

Hakim, Aldul Hamid, 2007, Al-Bayan, Maktabah As'adiyah Putra, Jakarta.

Romli, 1999, Muqaranah Mazahib Fil Ushul, 1 ${ }^{\text {st }}$ printed, Gaya Media Pratama, Jakarta. 